\section{SCIENCE IN GERMANY}

(From a German Correspondent.)

$\mathrm{D}^{2}$ URING the past year some interesting observations hive been published with reference to the alterations in animals through external influences. One series of these researches is by Weissmann, on the transformation of the Mexican Axolotl into an Amblystoma ( $Z$ eitschrift fïr Wissenschaftliche Zoologie, xxv., 1875, Supplement). It refers, of course, to a phenomenon which is not now new ; but it includes a number of original experiments and observations, and is especially important for the conclusions drawn from these. The Axolotl (Siredon Mexicanus) and its allies in Mexico retain there, during life, in the natural state, the form and organisation of the larvæ of our Tritons; but, in artificially breeding them in Europe, they sometimes undergo a metamorphosis into an Amblystoma, i.e. an animal of the form of our fully ceveloped Tritons. These peculiar departures from the natural behaviour of the Mexican Siredon, Weissmann desired to produce artificially, and with this view he entrusted the breeding of five eight-day larvæ to a lady, Frailiein v. Chauvain. All five actually underwent the desired transformation, having been put for six to eight months in water that was quite shallow, so that they were compelled frequently to leave the water, and become used to lungbreathing. Now, since, besides the Mexican Siredon species, which are never transformed in the natural state, there occur in the United States of North America quite similar animals, which, however, represent merely the temporary larva stage of various species of Amblystoma, the Mexican Siredon species have hitherto been regarded as forms that have remained at a lower stage of development, and, in the rare cases of metamorphosis by the action of changed conditions of life, have been incited to progression towards a higher stage. Weissmann, however, is now of a different opinion. He believes that the sudden and very remarkable transformation of the Siredon, which affects a whole series of organs, cannot be fully explained by the direct infuence of changed conditions of life; and that should one see in such a transformation the leap-like (sprun w weise) development of a new species or even genus, the hypothesis of a kind of life-force would be necessary. This teleological hypothesis should be avoided, according to Weissmann, and the transformation of the Siredon conceived as a not real but only apparent new formation of species, viz., as a reversion to a form which previously existed among the ancestors of the Siredon. Since the Perennibranchiata, at all events, represent the older form of the tailed amphibians, as it is indicated for the Amblystomas of North America in their Siredon-like larvæ, all Siredons are to be regarded as the descendants of Amblystomas, which were permanently depressed to that older form, and in their occasional metamorphoses have realised a reversion to the second phylogenetic stage (Amblystoma). Such a conception Weissmann supports by the following reasoning:-The possibility of Siredon having come from Amblystoma is proved by the fact that we sometimes see Triton-larvæ, which attain the full size and sex-forms of an adult Triton without being transformed; now the Tritons and Amblystomas are very similar animals, and their larvæare again extremely similar to the Siredon. But it is possible also to indicate the probable causes which forced the Amblystoma-like ancestors of the Siredon to reversion into the Perennibranchiate form. According to Humtoldt's view, the high table-lands of Mexico were formerly covered with extensive lakes, and the evaporation of such large water-surfaces must then have produced a very moist atmosphere, which is necessary to the naked amphibia living on land. Consequently, Amblystoma forms could at that time live in Mexico quite well. With disappearance of the waters, however, came the present extreme dryness of the air on the Mexican highlands, which allows only the Amphibia living in water to survive, and is therefore probably the reason why the Amblystoma larvæ have gradually quite ceased leaving the water and being transformed, and thus have constituted the present Siredon species. If, then, the occasional transformation of Siredon to Amblystoma may be explained as a reversion, the necessity ceases of supposing for so sudden a change : special life force, which in Weissmann's opinion is necessary, should his theory be rejected.

Similar experiments on the change of organisation through action of external infuences have been made by Schmankewitsch on low Crustaceans of the order of Branchiopoda. He also was led to experiment by natural occurrences. In the neighbourhood of Odessa (in Southern Russia) there is a salt lake which, with a view to salt production, was divided by a dam into two halves, so that in the lower, shut off part, salt was deposited in solid form, while the less salt upper portion alone, at the commencement, contained the Branchiopod Artemia saliza in large number. In the year 1871 that dam burst; the very salt water of the lower half of the lake was diluted to about $8^{\circ}$ of Baüme's areometer, and at the same time there were carried into it large masses of Artemia salina. After the dam was repaired the concentration of the same water rose in 1872 to $14^{\circ}, 1873$ to $18^{\circ}, 1874$ to $25^{\circ}$. At the same time the Artenia salina present underwent a remarkable change. In 1871 they still had their charac. teristic form of tail. In 1874 the two lobes of it, as also their bristles, had entirely disappeared. Simultaneously the gills were enlarged, in correspondence to the smaller proportion of oxygen in the very salt water. The body as a whole, however, decreased in size, so that the new form corresponded almost exactly to that of Artemia Mühlhazseniz, formerly regarded as a distinct species. This fact was tested experimentally; and the same results were obtained by artificial breeding in silt water of increasing degrees of concentration. Further, by the reverse experiment, the Artemia Miihlhansenii was, even in a few weeks, altered in the direction of Artemia salina, and this last form was, by continued dilution of the sals water, transformed into a Branchipus; i.e. a genus which, of larger dimensions than Artemic salina, has a somewhat different tail, and one abdominal segment more, and which also is propagated sexually, whereas partherio genesis is the rule with Artemia. In natural water-pools, with various proportions of salt, Schmankewitsch found (in accordance with his experiments) various transition stages between the forms named, so that the increase of the amount of salt reduces the Branchipus form in size, segmentation, and initial form of the post-abdomen; anc, with corresponding change of the gills, essentially modifies also the propagation, so that the strongest salt solutions harbour only Artemia Mïhllhausenit. From all these facts it appears that the direct induence of change. conditions of life may, in course of a few generations, transform one species, or even one genus, into another, and this in both directions; so that there can be as little question of the reality of a reversion as of that of imperceptible small changes, which, accumulating through long periods of time, suffice for the formation of a new form. Such facts, however, seem little fitted to give support to the opinion of Weissmann, viz., that reversion only is capable of working a rapid and remarkable change.

\section{SIEMENS' ELECTRIC LIGHT APPARATUS}

$\mathrm{THE}$ comparatively infrequent employment of electric light, considering the great success achieved in its production, would at first sight appear to be due to something in the application of the electricity itself. It has been repeatedly and satisfactorily proved that a continuous and powerful light can be produced by electricity, and the 